\title{
Research on Predicament and Countermeasure of College Students' Innovative Undertaking in a New Era
}

\author{
Dai Rui \\ Oxbridge College, Kunming University of Science and technology, Yunnan, China, 650000
}

Keywords: College students; Predicament of innovative undertaking; Countermeasure

\begin{abstract}
With the great growth of the economy of our country, employment patterns of college students have been radically changed. It is the new trend that college students innovative undertaking has been. However, there still have remained a lot of problems for the innovative undertaking of college students because of lacking social experience, although they have studied a lot and laid a strong basis of theoretical knowledge for innovative undertaking. So, the paper herein will analyze the predicament of college students' innovative undertaking and then propose the corresponding countermeasure under the current social situation.
\end{abstract}

\section{Introduction}

College enrollment has been greatly boomed in recent years and the scale of college graduates has been larger and larger, which leads to the grim employment situation. In other words, graduates may face the situation of unemployment as soon as they finish their college career. The great platform of "mass entrepreneurship and innovation" constructed by the country that is mentioned in the reports of 19th National Congress of the Communist Party of China has been attracting more and more powers to take part in the innovative undertaking. President Xi Jinping emphasizes that innovation is the soul of social progress and entrepreneurship is the crucial way to promote the social and economic development and improve people's livelihood. Under the new situation, college students' innovative undertaking will be greatly supported by policies and boasts the larger development space, which may also be an effective way to solve the difficulty of employment. Therefore, it is of great significance to study the predicament and countermeasure of college students' innovative undertaking, which is also the key to the employment of graduates. The paper herein will analyze the problems of college students' innovative undertaking and think deeper about the effective countermeasure, which will help stimulate students to start up their own business and then promote the employment. Thus, employment of college students may be practically solved.

\section{Predicament of college students innovative undertaking}

College students' innovative undertaking is still in low-level phase now. From the employment situation of college students, we can see there are so many factors that may have effect on the innovative undertaking of graduates, which may mainly be the impact of the traditional employment concepts, lack of entrepreneurship and ability of innovation and shortage of both experience and capital.

Traditional employment concepts. In traditional employment concepts, the meaning of owning a secure job is to find a position in a state-owned company or public institution, which is to say the pursuit of stability is the key of employment. Moreover, due to the public opinion, there are less entrepreneurs who may promote their own successful experience of entrepreneurship in colleges and universities, which leads to the loss of entrepreneurship atmosphere. So, colleges' graduates 
may face the situation of narrow employment opportunities and the predicament of entrepreneurship and suffer from stress.

Lack of entrepreneurship. There are five major factors of entrepreneurship which are passion, enthusiasm, adaption, leadership skills and ambition. Innovative undertaking is full of challenges and high risks, which needs entrepreneurs to be mature and have the ability to take a risk. But now most of graduates are not mature enough to burden the pressure of entrepreneurship and may cause negative modes when having difficulty or even choose to quit halfway.

Lack of entrepreneurial competence. Entrepreneurs have to be equipped with abilities of innovation, interpersonal communication, team collaboration and organization and management. For graduates who just start their business, it will be hard to realize their career, if they do what comes to their mind without deep and detailed analysis and planning.

Lack of experience. Since students spend more than three quarters of time in campus for study, they have less opportunities to step into society and take part in social practice. As a result, they may know little about the market, be unqualified for the management of a company and hard to realize the marketization of technological achievements and lack of social experience. All these disadvantages will increase the difficulty of innovative undertaking of college students and boost the probability of failure.

Lack of capital. It is the capital that is the key to decide whether the dream of innovative undertaking of graduates will come true or not. Although there are many graduates who have good ideas and the ability of entrepreneurship as well as the entrepreneurial team, they still may face the failure because of lacking capital. The resource of capital may mainly be from family, the loan and venture investment, but most of families can afford to provide the capital for establish a business. The state can provide start-up loan, but it may not be enough to solve the shortage of capital. It is difficult to get any financing to support for the innovative undertaking when students start their business.

\section{Analysis of countermeasure of college students innovative undertaking}

Facing all these existed problems, we will take active measures, which become more and more important for the innovative undertaking for college students. So, we should start from these aspects to solve the predicament.

Improve college students' entrepreneurial qualities. In the current overall situation, college students are the subjects of the innovative undertaking, so it is so crucial to improve the overall entrepreneurial qualities of graduates that we can ensure the success of the innovative undertaking. The self-improvement will not only do great help to the innovative undertaking but also be important to the learning of college students themselves in the future. First, college students should set clear goals. They should take an active part in practical activities and lectures to cultivate their abilities of organization and management. Second, college students should have abundant knowledge reserve when they learn specialized knowledge in school period. They should contact more knowledge of economics and management science to expand their horizon of knowledge in order to prepare well for the future innovative undertaking. Above all, college students should have plans for innovative undertaking because what innovative undertaking needs is not only enthusiasm and passion but also the overall planning. When having good ideas and programs, they should conduct extensive market researches and then analyze market condition to grasp the key of development, which can lead to the success of innovative undertaking. We should cultivate independent innovation and innovative qualities of each college student. Moreover, we should also make best use advantages of them and bypass the disadvantages. Comprehensive abilities and 
knowledge as well as the experience and acknowledgement of the world outside the school should also be enhanced to expand their horizon, grasp opportunities and facilitate the success of innovative undertaking.

Set up the right idea of entrepreneurship. Innovative undertaking of college students should be highly praised. Both the government and universities should vigorously promote the innovative undertaking and stimulate and support graduates to start up their business and set up the right idea of entrepreneurship. Innovative undertaking can not only solve the employment of graduates themselves but also help achieve their value of life, which can also promote the social development and solve the employment of others.

Actively carry out startup education and training. Colleges and Universities should invite well-known entrepreneurs and successful schoolmates to come back to hold lectures and discussions. They can share their entrepreneurial experience and skills with students and provide students with practicable advice in order that they can make effort to cultivate the entrepreneurship of students. Thus, graduates may be stimulated to take part in the entrepreneurial education and training. The building of entrepreneurial sense can lay a solid foundation for the future innovative undertaking.

\section{School-enterprise cooperation and cultivation of entrepreneurial experience}

School-enterprise cooperation is an important way to cultivate entrepreneurial talents with innovative thinking. Colleges and Universities should actively support entrepreneurial team and build up innovative spaces to cultivate abilities of creation. At the same time, colleges and universities can establish innovative undertaking clubs to encourage students to take greatly part in innovative undertaking and provide students with entrepreneurial experience.

\section{Improve the macro-environment of college students innovative undertaking}

Firstly, government should improve the service system simplify the procedure to ensure the efficiency. At the same time, government may also lower the loan threshold for students and provide them with entrepreneurial funds. Secondly, colleges and universities should strengthen the startup education for students and organize professional teams to improve abilities of organization and management of students, which can definitely promote the innovative undertaking.

\section{Conclusion}

Innovative undertaking of college students can not only help solve the employment of them but also release social employment pressure and promote both personal and social development. For graduates who just step into society, entrepreneurial sense and qualities are the key to nail the success. Entrepreneurial quality is the realization of self-comprehensive quality while sense of entrepreneurship is the way of thinking. Therefore, comprehensive quality and way of thinking mean a lot to the success of innovative undertaking. College students innovative undertaking can lay a concrete foundation for the economy of our country and promote the growth of traditional economy, leading to the improvement of lots of social problems.

\section{References}

[1] Li Liang, Liu Xiaoli, Zhang Guolei. "Students' entrepreneurial ability Internet plus" era culture exploration [J]. Science (a) Wenhui. 2016 (02): 41-42. 
[2] Zhang Hui, Kim Lijuan. College students' innovative research on entrepreneurial financing mo del [J]. Journal of Chifeng University (NATURAL SCIENCE EDITION). 2012 (22): 34-36.

[3] Li Liping. Optimization strategy for the path of College Students' innovation and entrepreneurs hip education [J]. school party construction and ideological education. 2016 (16): 84-86. 